\section{A profile of unintentional poisoning caused by household cleaning products, disinfectants and pesticides}

\author{
Perfil de intoxicações não intencionais com \\ produtos saneantes de uso doméstico
}

\begin{abstract}
Unintentional poisoning occurred mainly among children. The leading cause of such poisoning in Brazil, among consumer products was household cleaning products. For this study 2810 calls made to two poison control centers in the State of Rio de Janeiro between January 2000 and December 2002 were analyzed. Children under five were the most vulnerable group. More boys under 10 suffered accidental poisoning than girls, although above this age, the distribution was inverted. The calls received by poison control centers were mainly from health services within the first two hours following poisoning. The most frequent exposure routes were ingestion (90.4\%), followed by inhalation (4.3\%), skin and eye contact (2.4\% and $2 \%$ respectively). The products involved were bleach, petroleum derivates, rodenticides and pesticides. The main causes were products within the children's reach, storage in soft drink bottles, food mixed with rodenticides, incorrect product use, and kitchen utensils used for measured cleaning products. The most common outcome was that the patient was cured, although a lot of cases were lost to follow-up. Education programs are necessary in order to avoid these poisonings.
\end{abstract}

Poisoning; Household Products; Poison Control Centers
Rosaura de Farias Presgrave 1

Luiz Antônio Bastos Camacho 2

Maria Helena Simões Villas Boas 1

\section{Introduction}

One of the most common medical emergencies in childhood is unintentional poisoning, although the profile and risk of poisoning vary between countries 1,2,3,4. Even though the outcomes of these events are rarely critical, they do cause considerable concern particularly because young children under five are frequently affected $5,6,7,8$.

Epidemiological surveillance is necessary to assess the magnitude of the problem and the major risk factors, so that preventive measures can be taken. Brazil has a network of 36 poison control centers located in different regions of the country and the National Information System on Poisoning (Sistema Nacional de Informações Tóxico-Farmacológicas - SINITOX) compiles the relevant data. There are two poison control centers in the state of Rio de Janeiro, which has a population of 14,391,282 inhabitants, $96 \%$ of whom live in urban areas 9 .

In Brazil in general, drugs are the main cause of poisoning, but unintentional poisoning is most commonly caused by the ingestion of household cleaning products, pesticides or corrosives 10,11,12. Among household products, cleaning products are present in most homes due to their wide variety of uses. Several of these products such as bleaches, pesticides, corrosive substances, surfactants and others are complex mixtures of chemicals with an extensive range of 
toxic potentials. Unlike medicines and cosmetics, the containers of these household cleaning products are usually stored under sinks in kitchens and on floors in backyards, within the reach of children. In addition, parents often disregard the potential toxicity and the warnings on the labels of these products, or store them in new containers, thus increasing the risk of unintentional poisoning amongst children $6,13,14$.

The purpose of this paper is to describe the epidemiological profile of unintentional poisoning that was caused by household cleaning products and took place in Rio de Janeiro between 2000 and 2002, assessing the distribution by age, gender, route of exposure, product involved, risk factors and outcomes.

\section{Methods}

In a retrospective review of files from two poison control centers in Rio de Janeiro State, dated between 1 January 2000 and 31 December 2002, a selection was made of those cases of human exposure that registered unintentional poisoning at home in an urban area, and reported the involvement of household cleaning products. The variables analyzed were: age, gender, caller, time elapsed before call, route of exposure, product, determinant factor of poisoning and outcomes.

In order to organize and summarize the data, information relating to the determinant factor was categorized as follows: (1) not identified - description of the accident was not available; (2) product was within the reach of children or mentally handicapped person - the record was absent but the package was found near the victim or in his/her hands, the product was identified in the body of the victim, or he/she presented symptoms of poisoning; (3) kitchen utensil - product was in a glass, a cup, a spoon or a dish; (4) during use - accidental exposure occurred during product use/application; (5) incorrect use - product was used for a purpose different to that which was recommended by the manufacturer or instructions of use were disregarded; (6) product was mistaken for medicine because of its appearance or container; (7) product was in a different container to the original; (8) product was mistaken for food; (9) mixture - product was used mixed with others products.

The outcomes were categorized according to the information obtained in follow up and described in records as follows: (a) cure - patient without symptoms or patient discharged from hospital; (b) no confirmed cure - patient with symptoms or patients in treatment; (c) unknown - patient lost to follow-up or record without in- formation; (d) death - patient died; (e) others - the case was classified as not poisoning or the caller asked for information only.

Data sets obtained from centers were revised for consistency and completeness. Frequency tables were generated using univariate analysis, indicating the profile of the accidents. The population of Rio de Janeiro State, taken from the 2000 Demographic Census 9 , was used to calculate rates. The statistical significance of differences in proportions was assessed using the chi-squared test. 95\% confidence intervals were constructed based on estimates. All data were coded and the Epi Info software version 6.04 (Centers for Disease Control and Prevention, Atlanta, USA) was used to analyze data.

The study was approved by the Ethics Committee of Human Research at the Oswaldo Cruz Foundation and by coordinators at the poison control centers.

\section{Results}

In a period of three years (2000-2002) the Rio de Janeiro poison control centers received 13,429 calls involving human exposures. Of these calls, $2,810(20.9 \%)$ were identified as unintentional poisoning due to household cleaning products. Forty five cases (1.6\%) were from others states in Brazil.

\section{Age and gender}

The age range was between 18 days old and 91 and the mean age was 8.9 (standard deviation = 15.9). The age was unknown in 48 cases. 2005 cases $(71.4 \%)$ occurred in children under five years of age, with a peak between the ages of 1 and 2 (52.1\%).

Above the age of 10, the proportion of females was $57.1 \%$ (323/566), whereas below 10 this proportion was $44.5 \%(975 / 1,200)(\mathrm{p}<0.000)$.

\section{Calls}

The average utilization rate of the poison control centers of Rio de Janeiro was 4.5 calls per 1,000 inhabitants per year. In most cases (87\%) calls were from health services: public services (54.2\%), private services (31.8\%) and unknown (1\%); $9.8 \%$ calls were made from the home of the person who had been poisoned, while $3 \%$ were from doctors and $0.2 \%$ from unknown callers. 


\section{Time elapsed before calls}

2035 calls $(72.4 \%)$ to the poison control centers occurred within the first two hours following poisoning, 198 calls $(7.1 \%)$ were made between two and six hours, 190 calls (6.8\%) after six hours and in the case of 387 calls $(13.8 \%)$ the time was unknown.

\section{Route of exposure}

Ingestion accounted for $90.4 \%$ of all exposures, followed by inhalation (4.3\%), skin contact $(2.4 \%)$ and eye contact (2\%). Children under the age of five were exposed by almost all routes. In adults, inhalation was the second most common route of poisoning (Table 1).

\section{Products}

Among the products involved in unintentional poisoning, bleach was the most reported across all ages. The others were petroleum derivates, rodenticides, pesticides, disinfectants, detergents and corrosives. In all major categories of products involved in poisoning, children under the age of 5 accounted for more than $70 \%$ of the reported incidents (Table 2). The most frequent means was ingestion. Pesticides were also responsible for intoxication through inhalation, while corrosives caused burns to the skin and eyes (Table 3 ).

Table 1

Route of exposure in unintentional poisoning caused by household cleaning products, disinfectants and pesticides according to age. Rio de Janeiro, Brazil, 2000-2002.

\begin{tabular}{|c|c|c|c|c|c|c|c|c|}
\hline \multirow[t]{2}{*}{ Routes } & \multicolumn{6}{|c|}{ Age (years) } & \multirow[t]{2}{*}{ Total } & \multirow[t]{2}{*}{$\%$} \\
\hline & $<5$ & $5-14$ & $15-29$ & $30-59$ & $60+$ & Unknown & & \\
\hline Oral & 1,908 & 236 & 146 & 161 & 54 & 34 & 2,539 & 90.4 \\
\hline Inhalation & 16 & 13 & 16 & 56 & 10 & 10 & 121 & 4.3 \\
\hline Dermal & 36 & 9 & 4 & 13 & 5 & 1 & 68 & 2.4 \\
\hline Ocular & 26 & 6 & 7 & 13 & 2 & 2 & 56 & 2.0 \\
\hline Nose & 7 & - & - & 1 & - & - & 8 & 0.3 \\
\hline Ear & 1 & - & - & - & - & - & 1 & - \\
\hline Intramuscular & - & - & 1 & - & - & - & 1 & - \\
\hline Unknown & 11 & 3 & - & 1 & - & 1 & 16 & 0.6 \\
\hline Total & 1,994 & 264 & 174 & 244 & 71 & 47 & 2,810 & 100.0 \\
\hline
\end{tabular}

Table 2

Distribution of toxic agents by age in unintentional poisoning caused by household cleaning products, disinfectants and pesticides. Rio de Janeiro, Brazil, 2000-2002.

\begin{tabular}{|c|c|c|c|c|c|c|c|}
\hline \multirow[t]{2}{*}{ Product } & \multicolumn{6}{|c|}{ Age (years) } & \multirow[t]{2}{*}{ Total } \\
\hline & $<5$ & $5-14$ & $15-29$ & $30-59$ & $60+$ & Unknown & \\
\hline Bleaches & 498 & 106 & 53 & 99 & 22 & 7 & 785 \\
\hline Petroleum derivates & 419 & 32 & 20 & 15 & 5 & 6 & 497 \\
\hline Rodenticides & 259 & 43 & 27 & 13 & 7 & 6 & 355 \\
\hline Household pesticides & 204 & 29 & 29 & 40 & 4 & 8 & 314 \\
\hline Disinfectants & 209 & 12 & 9 & 16 & 7 & 5 & 258 \\
\hline Unknown & 129 & 19 & 12 & 23 & 7 & 2 & 192 \\
\hline Detergents/Cleaners & 130 & 18 & 11 & 13 & 11 & 7 & 190 \\
\hline Corrosives & 119 & 8 & 12 & 23 & 5 & 5 & 172 \\
\hline Others & 38 & - & 1 & 3 & 3 & 2 & 47 \\
\hline Total & 2,005 & 267 & 174 & 245 & 71 & 48 & 2,810 \\
\hline
\end{tabular}


Table 3

Distribution of toxic agents by route of exposure in unintentional poisoning from household cleaning products, disinfectants and pesticides. Rio de Janeiro, Brazil, 2000-2002 ( $n=2,810)$

\begin{tabular}{|c|c|c|c|c|c|c|c|c|c|}
\hline Product & Oral & Inhalation & Skin contact & Eye contact & Unknown & Nose & Ear & Intramuscular & Total \\
\hline Bleaches & 733 & 32 & 3 & 16 & 1 & - & - & - & 785 \\
\hline Petroleum derivates & 473 & 9 & 5 & 3 & - & 7 & - & - & 497 \\
\hline Rodenticides & 349 & 1 & 1 & - & 4 & - & - & - & 355 \\
\hline Household pesticides & 232 & 42 & 27 & 5 & 6 & - & 1 & 1 & 314 \\
\hline Disinfectants & 234 & 10 & 6 & 7 & - & 1 & - & - & 258 \\
\hline Unknown & 177 & 8 & 4 & 2 & 1 & - & - & - & 192 \\
\hline Detergents/Cleaners & 177 & 2 & 1 & 9 & 1 & - & - & - & 190 \\
\hline Corrosives & 130 & 10 & 18 & 12 & 2 & - & - & - & 172 \\
\hline Others & 41 & 5 & - & 1 & - & - & - & - & 47 \\
\hline Total & 2,546 & 119 & 65 & 55 & 15 & 8 & 1 & 1 & 2,810 \\
\hline
\end{tabular}

\section{Risk factors}

A risk factor attributable to the poisoning was identified in 1,569 (55.8\%) cases as described in Table 4 . In $77.4 \%$ of them the product was within the reach of a child or mentally handicapped person. The second most frequent risk factor for intoxication was the storage of a product in a container that was different to the original. This appeared to be associated to poisoning in both children and adults. In $82.8 \%$ of cases the product was in stored in soft drink bottles and $8.6 \%$ in medicine containers and had been applied to the ears, nose or eyes.

Among the accidents that took place during product use, $43.5 \%$ occurred among young children aged under four who had ingested rat killer or insecticide and $18.5 \%$ were due to the inhalation of bleach, petroleum derivates, disinfectants or pesticides. Other routes of exposure include contact of corrosives with the eyes or skin.

65 cases of poisoning were caused by the incorrect use of a product. The most frequent errors included treating head lice with pesticides, using an excessive amount of pesticides in a closed environment, using household cleaning products in the mistake that they were medicines or cosmetics and teenage pranks.

Forty four cases of unintentional poisoning were caused by the use of kitchen utensils (glasses, cups or spoons) to measure or dilute household cleaning products. Glasses and cups were used to store hypochlorite, anionic surfactants and petroleum derivates. Corrosive products were left on spoons and rodenticides on dishes.

In nine cases $(0.6 \%)$, poisoning was caused by the inhalation of vapors generated by a mixture of bleaches with other cleaning products (disinfectants or acids). In seven cases, detergents, disinfectants or pesticides were swallowed because they had been mistaken for juices or candies. In six cases, the container or the household cleaning product was mistaken for medication.

\section{Outcomes of the poisoning}

The most frequent outcome among the cases of poisoning with household products was cure (Table 5). The fatality rate was $0.3 \%$, which occurred among children and older adults due to the ingestion of rodenticides and corrosives.

\section{Discussion}

The findings of this study were consistent with the literature with respect to age, sex and routes of exposure 15,16,17,18. Bleaches, petroleum derivates and pesticides were the products that were most commonly involved 1,2,3,7,8. As in Europe and the United State household cleaning products are the substances that are most commonly ingested by children aged between 0 and 4 6,8,10,11,12. The utilization rate of the poison control center in Rio de Janeiro was considered very low compared to others countries suggesting that the population of Rio de Janeiro State underutilizes the service 19,20 . In contrast to Rio de Janeiro, $64 \%$ of calls in Chile were from patients' homes and $30 \%$ were from health services 21 .

Children under five years-old were the major risk group for unintentional poisoning, on account of their curiosity in exploring their surroundings and the regular hand-mouth contact 
Frequency of risk factors in unintentional poisoning by household cleaning products, disinfectants and pesticides. Rio de Janeiro, Brazil, $2000-2002$.

\begin{tabular}{|c|c|c|c|c|c|c|c|c|c|}
\hline Product & $\begin{array}{l}\text { Products } \\
\text { within } \\
\text { reach }\end{array}$ & $\begin{array}{c}\text { Storage in } \\
\text { non original } \\
\text { bottle }\end{array}$ & $\begin{array}{c}\text { During } \\
\text { use }\end{array}$ & $\begin{array}{l}\text { Incorrect } \\
\text { use }\end{array}$ & $\begin{array}{l}\text { Kitchen } \\
\text { utensil }\end{array}$ & $\begin{array}{l}\text { Mixture of } \\
\text { products }\end{array}$ & $\begin{array}{l}\text { Mistaken } \\
\text { for food }\end{array}$ & $\begin{array}{c}\text { Mistaken } \\
\text { for medicine }\end{array}$ & Total \\
\hline Bleaches & 353 & 68 & 13 & 4 & 13 & 8 & - & 1 & 460 \\
\hline Petroleum derivates & 248 & 12 & 5 & 6 & 8 & - & - & - & 279 \\
\hline Rodenticides & 140 & - & 38 & - & 3 & - & 1 & - & 182 \\
\hline Household pesticides & 110 & 5 & 15 & 22 & 1 & 1 & 2 & 3 & 159 \\
\hline Unknown & 69 & 5 & 10 & 3 & 1 & - & 3 & 2 & 93 \\
\hline Detergents/Cleaners & 61 & 13 & 5 & 19 & 10 & - & 1 & - & 109 \\
\hline Disinfectants & 123 & 7 & 10 & 1 & 3 & - & - & - & 144 \\
\hline Corrosives & 90 & 2 & 10 & 9 & 5 & - & - & - & 116 \\
\hline Others & 20 & 4 & 2 & 1 & - & - & - & - & 27 \\
\hline Total & 1,214 & 116 & 108 & 65 & 44 & 9 & 7 & 6 & 1,569 \\
\hline
\end{tabular}

Table 5

The outcomes of unintentional poisoning cases caused by household cleaning products, disinfectants and pesticides by age. Rio de Janeiro, Brazil, 2000-2002.

\begin{tabular}{|c|c|c|c|c|c|c|c|c|}
\hline \multirow[t]{2}{*}{ Outcome } & \multicolumn{6}{|c|}{ Age (years) } & \multirow[t]{2}{*}{ Total } & \multirow[t]{2}{*}{$\%$} \\
\hline & $<5$ & $5-14$ & $15-29$ & $30-59$ & $60+$ & Unknown & & \\
\hline Cured & 1,455 & 201 & 122 & 167 & 54 & 30 & 2,029 & 72.2 \\
\hline Cure unconfirmed & 88 & 13 & 7 & 19 & 2 & 1 & 130 & 4.6 \\
\hline Other & 7 & 1 & - & 1 & 1 & - & 10 & 0.4 \\
\hline Death & 5 & - & - & - & 3 & 1 & 9 & 0.3 \\
\hline Unknown & 450 & 52 & 45 & 58 & 11 & 16 & 632 & 22.5 \\
\hline Total & 2,005 & 267 & 174 & 245 & 71 & 48 & 2,810 & 100.0 \\
\hline
\end{tabular}

that is common during this age. The major risk factor for unintentional poisoning was that the toxic products were easily accessible. The inadequate storage in homes often led to the ingestion of those products $3,8,14,22,23,24,25$. In many instances the product was within the reach of children or was stored in beverage bottles and caused unintentional poisoning among both children and adults.

The panic caused by poisoning is not directly proportional to the real toxicity of the substance involved, but is probably because it is mostly children that are involved 5 . The analysis of calls in this study demonstrated that the victims were taken to the emergency room independently of the severity of the case. The main callers to poison control centers were public hospitals, indicating that this form of health care is usually paid for by the government. Due to the wide range of poisoning agents around, it would be prudent to seek out the expertise of the poisoning control centers in order to ensure correct first-aid procedures are followed, but the results showed that inhabitants of Rio de Janeiro State do not regularly use the poison control center.

The effect of poisoning is dose dependent. Household cleaning products have an unpleasant taste and therefore only small amounts are ingested. This, along with the short time between ingestion and calling the poison control centers, might have contributed to the fact that there were no fatal outcomes in these cases.

The color and flavor of medicines are thought to increase the risk of poisoning, because they can be mistaken for candy or harmless substances 4,26. In Brazil, bleaches, disinfectants and softeners are often sold illegally in beverage containers. Children and adults were poisoned because they 
had swallowed bleach that was in such a container and had mistaken it for a soft drink or with water. Naphthalene is also a problem because it is traded as little white balls that are similar in appearance to coconut candy. Although prohibited, this product is sold as an insect repellent. Besides swallowing, children also put it in their ears and noses.

As in other regions, the age groups that were most vulnerable to unintentional poisoning by pesticides in Rio de Janeiro State were children and the elderly $3,4,6,27$. In the study period, children below the age of five and older adults died due to the ingestion of rodenticides. Children and the elderly appeared to be the age groups most vulnerable to poisoning by pesticides, and to the most severe forms that led to death.

Unintentional misuse was one of the major risk factors for poisoning in children. In other countries, the use of child-resistant containers and of educational programs regarding the appropriate usage and storage of dangerous products in the home has been shown to reduce the incidence of unintentional poisoning $1,4,5,7,21,25,26$. Education might also address other risk factors such as the use of kitchen utensils to measure household cleaning products. Children often put into their mouths spoons and glasses that contain insecticides, corrosives, kerosene, disinfectants, soaps and detergents.

In Brazil, there are few epidemiological reports about poisoning, although this is important to improve the monitoring of poisoning. The data indicated a trend towards high incidence rates and low fatality rates as described in the literature 6,23,26,28,29,30, although such information may be biased on account of the difficulty to followup. Particularly in Rio de Janeiro, the epidemiological analysis of unintentional poisoning lacks important data such as determinant factors and outcomes. These variables were categorized and this may be another potential source of bias in this retrospective study.

\section{Conclusion}

Although the assessment of calls to poison control centers of Rio de Janeiro demonstrated low morbidity and case fatality rates of unintentional poisoning, risk managers must interpret these findings with caution. They may be due to the underreporting of cases since the use of the poison control centers by the population was low.

Education and prevention programs are necessary to increase the population's awareness of the risks of poisoning at home, targeting mainly the appropriate storage of products in the home, knowledge about the toxicity of these products, the reading of labels, and the advertising of the telephone number of poison control centers in order to prevent and control these poisoning events.

\section{Resumo}

Intoxicações não-intencionais ocorrem principalmente na infância. No Brasil, os produtos de limpeza doméstica são as principais causas desses eventos. Para este estudo foram analisados 2.810 casos registrados nos dois centros de controle de intoxicação do Estado do Rio de Janeiro, no período de janeiro de 2000 a dezembro 2002. O grupo mais vulnerável foi o de crianças de até cinco anos de idade. Meninos de até dez anos foram mais intoxicados do que meninas. A partir dessa faixa etária, a distribuição foi invertida. Os centros de controle de intoxicação foram chamados principalmente por serviços de saúde no período de até duas horas após o envenenamento. As vias de exposição mais freqüentes foram ingestão (90,4\%), inalação
(4,3\%), dérmica (2,4\%) e ocular (2\%). Os produtos envolvidos foram alvejantes, derivados de petróleo, raticidas e pesticidas. As principais causas foram: produto ao alcance de crianças, estocagem em garrafas de refrigerantes, uso de alimentos com raticidas, uso incorreto do produto, e utensílios de cozinha com produtos de limpeza. O desfecho mais freqüente foi cura apesar do grande número de casos perdidos durante o seguimento. São necessários programas educacionais a fim de evitar esses eventos.

Envenenamento; Produtos Domésticos; Centros de Controle de Intoxicações 


\section{Contributors}

R. F. Presgrave was responsible for the planning and execution of the study and revision of the final text. L. A. B. Camacho and M. H. S. Villas Boas discussed the results and drew up the final text.

\section{References}

1. Lawson GR, Craft AW, Jackson RH. Changing pattern of poisoning in children in Newcastle, 1974-81. Br Med J (Clin Res Ed) 1983; 287:15-7.

2. Andiran N, Sarikayalar F. Pattern of acute poisoning in childhood in Ankara: what has changed in twenty years? Turk J Pediatr 2004; 46:147-52.

3. Uziel Y, Adler A, Aharonowitz G, Franco S, Fainmesser P, Wolach B. Unintentional childhood poisoning in the Sharon area in Israel: a prospective 5-year study. Pediatr Emerg Care 2005; 21:248-51.

4. Wilkerson R, Northington L, Fisher W. Ingestion of toxic substances by infants and children: what we don't know can hurt. Crit Care Nurse 2005; 25:35-44.

5. White NC. Poisons and panic! Vet Hum Toxicol 1997; 39:170-2

6. Meredith TJ. Epidemiology of poisoning. Pharmacol Ther 1993; 59:251-6.

7. Bouton JM, Steppé M. Particularities in children poisoning. Acta Clin Belg Suppl 1990; 13:51-6.

8. Watson WA, Litovitz TL, Rodgers GC, KleinSchwartz W, Reid N, Youniss J, et al. 2004 Annual Report of the American Association of Poison Control Centers Toxic Exposure Surveillance System. Am J Emerg Med 2005; 23:586-666.

9. Instituto Brasileiro de Geografia e Estatística Censo demográfico 2000. http://www.ibge.gov.br/ home/estatistica/população/censo2000 (acessed on $08 /$ Nov/2005).

10. Sistema Nacional de Informações Tóxico-Farmacológicas. Casos registrados de intoxicação humana e envenenamento. Brasil, 2000. http://www. fiocruz.br/sinitox/sinitox2000.htm (accessed on 08/Nov/2005).

11. Sistema Nacional de Informações Tóxico-Farmacológicas. Casos registrados de intoxicação humana e envenenamento. Brasil, 2001. http://www. fiocruz.br/sinitox/sinitox2001.htm (accessed on 08/Nov/2005).
12. Sistema Nacional de Informações Tóxico-Farmacológicas. Casos registrados de intoxicação humana e envenenamento. Brasil, 2002. http://www. fiocruz.br/sinitox/sinitox2002.htm (accessed on 08/Nov/ 2005).

13. Mrvos R, Dean BS, Krenzelok EP. Illiteracy: a contributing factor to poisoning. Vet Hum Toxicol 1993; 35:466-8.

14. Casanovas AB, Martinez EE, Cives RV, Jeremias AV, Sierra RT, Cadranel S. A retrospective analysis of ingestion of caustic substances by children: ten-year statistics in Galicia. Eur J Pediatr 1997; 156:410-4.

15. Badcock NR. Detection of poisoning by substances other than drugs: a neglected art. Ann Clin Biochem 2000; 37:146-57.

16. Lam LT. Childhood and adolescence poisoning in NSW, Australia: an analysis of age, sex, geographic, and poison types. Inj Prev 2003; 9:338-42.

17. Afshari R, Majdzadeh R, Balali-Mood M. Pattern of acute poisoning in Mashhad, Iran 1993-2000. J Toxicol Clin Toxicol 2004; 42:965-75.

18. Beirens TMJ, van Beeck EF, Dekker R, Brug J, Raat H. Unsafe storage of poisons in homes with toddlers. Accid Anal Prev 2006; 38:772-6.

19. Vassilev ZP, Marcus S, Jennis T, Ruck B, Swenson R, Rego G. Rapid communication: sociodemographic differences between counties with high and low utilization of a regional poison control center. J Toxicol Environ Health A 2003; 66:1905-8

20. Forrester MB. Association between sociodemographic factors and exposures and utilization of poison centers in Texas, 1998-2002. J Toxicol Environ Health A 2005; 68:755-61.

21. Mena C, Bettini M, Cerda P, Concha F, Paris E. Epidemiología de las intoxicaciones en Chile: una década de registros. Rev Méd Chile 2004; 132:493-9.

22. Benson EB, Klein-SchwartzW, Oderda GM, Lucy JS. Warning labels: a source of toxicity information for parents. Clin Pediatr (Phila) 1984; 23:441-4. 
23. Neidich G. Ingestion of caustic alkali farm products. J Pediatr Gastroenterol Nutr 1993; 165:75-7.

24. Wogalter MS, Jarrard SW, Simpson SN. Influence of warning label signal words on perceived hazard level. Hum Factors 1994; 36:547-56.

25. Jones AL, Dargan PI. What's new in toxicology? Current Paediatrics 2001; 11:409-13.

26. Berry M. Poisoning. Can Pharm J 1996; 129:19-22.

27. Bass J K, Ortega L, Rosales C, Petersen NJ, Philen RM. What's being used at home: a household pesticide survey. Rev Panam Salud Pública 2001; 9:138-44.
28. Repetto MR. Pediatric poisonings due to cleaning agents reported in 1994 to the toxicological information service of Seville, Spain. Vet Hum Toxicol 1996; 38:435-7.

29. Riordan M, Rylance G, Berry K. Poisoning in children 4: household products, plants and mushrooms. Arch Dis Child 2002; 87:403-6.

30. Runyan CW, Perkis D, Marshall SW, Johnson RM, Coyne-Beasley T, Waller AE, et al. Unintentional injuries in the home in the United States. Part II: morbidity. Am J Prev Med 2005; 28:80-7.

Submitted on $07 / \mathrm{Feb} / 2007$

Final version resubmitted on $31 /$ Oct $/ 2007$

Approved on 13/Nov/2007 